\title{
PROJECT DELAY: KEY ELECTRICAL CONSTRUCTION FACTORS IN HONG KONG
}

\author{
Betty W. Y. CHIU ${ }^{\mathrm{a}}$, Joseph H. K. LAI ${ }^{\mathrm{b}}$ \\ ${ }^{a}$ Department of Construction, Hong Kong Institute of Vocational Education, Tsing Yi, Hong Kong \\ ${ }^{b}$ Department of Building Services Engineering, The Hong Kong Polytechnic University, Hung Hom, Hong Kong
}

Received 15 Dec 2016; accepted 30 Mar 2017

\begin{abstract}
The price of construction project delays is too substantial to pay. Electrical construction is a critical activity influencing project completion, but research on its delay factors was limited. Aimed at contributing knowledge to this niche area, a study was conducted in Hong Kong. 56 delay factors, in 10 groups, were found with electrical construction. Processing the data of a survey on 64 consultants and 68 contractors revealed "insufficient labour", "late decision making of client" and "insufficient electrical contractor" as the top delay factors. Strong agreements on the importance rankings of the delay factors existed between the consultant and contractor groups, and the principal factor components were "incompetent project team members", "lack of skillful labour" and "poor on-site planning". Besides discussing the common problems underlying the delay factors, recommendations were made for avoiding the problems. An understanding of the delay factors would help construction stakeholders in taking proactive measures to prevent project delay. The approach of the study can serve as reference for similar, future research in construction management.
\end{abstract}

Keywords: building, construction, consultant, contractor, delay, electrical.

\section{Introduction}

The traditional philosophy in project management places a great deal of emphasis on the extent to which the planned progress and outcome of projects are fulfilled. But project delays, i.e. time overruns beyond the prescribed project completion date (Assaf, Al-Hejji 2006), are invariably common in the construction industry. These often result in the overrun of the construction budget allocated at project inception as well as the delay of potential income that could be obtained within the operation of constructed facilities (Kazaz et al. 2012).

In construction projects, electrical installation is among a range of essential, specialist trades of work (Yik, Lai 2008). Failure to complete electrical installations (e.g. transformer, switchboard) on time would lead to delay in setting up on-site provisions, such as illumination for interior spaces of a building under construction, or power supply for some construction activities, e.g. hoisting operations. Testing and commissioning for engineering services (e.g. chillers, water pumps) and energizing them before actual operation also require proper completion of the relevant electrical installations. Any late completion of such events in the critical path of a construction programme would result in an overall project delay. Identification of their delay factors, therefore, is of vital importance in ensuring timely project completion (Fong et al. 2006; Odeh, Battaineh 2002).
In metropolises such as Hong Kong, where the land and property prices are exorbitant, the consequence of delay in building projects is too substantial to tolerate. Completion of a building is signified by obtaining an Occupation Permit from the Buildings Department (Law 2002). For this, a pre-requisite is satisfactory completion of the electrical installation for the building. According to the Electricity (Wiring) Regulations, any fixed electrical installation shall, after completion and before it is energized for use, be inspected, tested and certified by registered electrical contractors or workers (Lai et al. 2011).

While the problem of project delay has been widely studied (Al-Momani 2000; Assaf et al. 1995; Chan, Kumaraswamy 1997; Fong et al. 2006; Long et al. 2004), there was hardly any research on the factors of the electrical trade that give rise to delays in construction projects. As such, a study was initiated to identify the principal delay factors of the electrical trade.

\section{Literature review}

\subsection{Electrical installations and construction}

Electrical installations are indispensable for all construction projects. Electrical construction is critical in construction projects because electrical installations are sophisticated and their connection with other building 
systems such as structural, mechanical and communication systems requires seamless coordination (Horman et al. 2006).

Electrical contractors are mainly responsible for the installation, connection and testing of the electrical systems and components. The competitive nature of the construction industry has driven electrical contractors to target higher productivity. Therefore, many contractors strive for better planning in order to improve time management (Menches et al. 2008).

For electrical construction, while there is a significant volume of literature such as Horman et al. (2006), Menches and Hanna (2006) and Menches et al. (2008) focusing on look-ahead scheduling methods that could help improve project time management, there are unique challenges in electrical construction that contribute to project delay. Some of the influential factors are lack of on-site coordination and interaction with other trades, subcontractor status, high technical and quality requirements, poor site management and supervision skills, and skilled labour shortage (Chi et al. 2009; Hanna et al. 2005; Horman et al. 2006; Smith, Hinze 2010).

\subsection{Causes of delay and delay factors}

Many studies showed that project delay is a common issue in the construction industry (Chan, Kumaraswamy 1993; Doloi et al. 2012; Hwang et al. 2013; Rwelamila, Hall 1995; Sweis et al. 2008); less than $30 \%$ of building projects are completed on time although the average time overrun is less than 30\% (Assaf, Al-Hejji 2006; Akogbe, Feng 2013; Chan, Kumaraswamy 2002). Practitioners, therefore, should foresee and avoid potential delay factors that are likely to jeopardize their current and future projects (Sweis et al. 2008; Wang et al. 2014).

In the study of Assaf et al. (1995), 56 causes of delay were divided into nine groups for examination of their relative importance. Measured by an importance index, "preparation and approval of shop drawings", "delay in contractor's progress" and "design changes" were regarded by the contractors as important delay factors. Assaf and Al-Hejji (2006) further conducted a survey on 73 causes of delay in large construction projects, and the result showed that the most common cause of delay was "change order". Grounded on the work of Assaf et al. (1995), El-Razek et al. (2008) identified 87 delay causes and revealed similar important factors such as "financing by contractor during construction", "delay in contractor's payment by owner", "design changes by owner or his agent during construction" and "partial payments during construction". But the rank correlation test results showed that the parties involved did not agree on the relative importance of various delay factors.

Odeh and Battaineh (2002) carried out a survey to identify the most important causes of delay in construction projects from the perspectives of contractors and consultants. The calculated relative importance indices indicated that "owner interferences", "inadequate con- tractor experience", "financing and payments", "labour productivity", "slow decision making", "improper planning and subcontractors" are the most important factors. Sambasivan and Soon (2007) also used the same index to determine the importance of the same 28 delay causes perceived by clients, consultants and contractors in Malaysia. In addition to the revelation of similar importance delay causes, the study identified the importance of "poor site management", "equipment availability and failure" and "lack of communication between parties" in contributing to project delay.

In Hong Kong, Chan and Kumaraswamy (1997) conducted a survey to evaluate the relative importance of 83 delay factors involved in construction projects. It showed that the 5 principal factors were "poor risk management and supervision", "unforeseen site conditions", "slow decision making", "client-initiated variations" and "work variations". But significant disagreement existed between clients, consultants and contractors in respect of the ranking of the delay factors.

Project delay due to a particular trade of building services - fire services installation - was studied. As identified in Fong et al. (2006), where a questionnaire survey on 52 contractors and 32 consultants was conducted, there were 49 pre-determined factors causing delay in building construction projects. The results also showed that "improper site co-ordination and management of electrical and mechanical installations", "late decision making of the client" and "insufficient project staff" were the major delay factors.

\subsection{Categorization and perceptions of delay factors}

From most of the previous studies, it is apparent that the ranking of delay factors could indicate the areas of construction practices where improvements are needed. However, there is no consensus on which among the various construction delay factors should be tackled with priority. One reason for this is the diverse perspectives taken to study the problem of project delay (Sweis et al. 2008). An added reason is that a large number of activities are involved in a construction project. Any deviation in the activities can prevent the systematic flow of construction work, causing time-based anomalies (Kazaz et al. 2012). Thus, the existence of delay in construction projects is related to a multitude of factors in different aspects.

Some studies revealed that different project parties had different perceptions of the delay factors. For instance, contractors and consultants were found to have different perceptions of the importance of the labour related factors such as "site management and supervision", "workload of project staff", "shortage of labour", "approval procedure for equipment" and "working experience of staff" (Assaf, Al-Hejji 2006; Chan, Kumaraswamy 1997; Fong et al. 2006). From some other studies, owners and contractors had no agreement on the significance of a number of factors, including "design changes", "financing and payment for construction works", "poor 


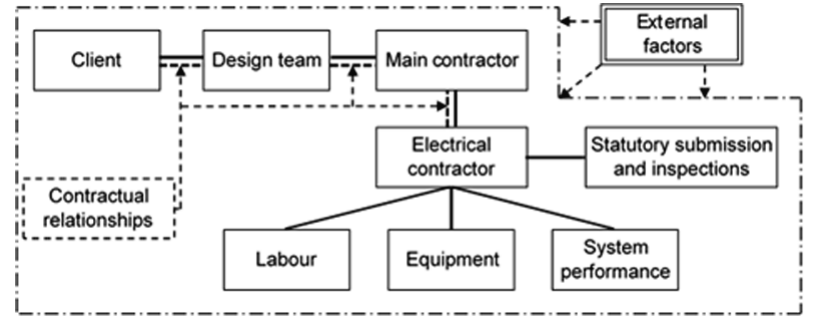

Fig. 1. Map of delay factor groups

contract management", "poor site condition", "shortage of resources/materials" and "improper planning" (Assaf et al. 1995; Chan, Kumaraswamy 1997; Mezher, Tawil 1998; Semple et al. 1994).

As shown above, earlier studies mostly concentrated on some particular sectors of the construction industry, such as roads and highways, buildings, and water supply projects. While such studies have provided important findings for the construction industry, it is imperative to identify delay factors of electrical construction, which is a specific trade of work affecting the timing of project completion.

On the basis of the above review, a total of 56 delay factors, as summarised in Table 1, were identified as applicable to the electrical trade of construction projects. Such factors were categorized into 10 groups. They consist of nine groups within a project boundary: client, design team, main contractor, electrical contractor, labour, equipment, system performance, statutory submission and inspections, and contractual relationships; and a group of external factors. A map of these factor groups, as depicted in Figure 1, forms a useful framework for formulating the research method for the current study.

\section{Data and method}

As the main aim of this study was to identify project delay factors from the perspectives of key parties involved in the design, construction, testing and commissioning of electrical installation, the targets from which data were collected are electrical consultants and contractors. Contact information on the consultants and contractors was obtained from the membership directories of the Association of Consulting Engineers of Hong Kong and the Hong Kong Federation of Electrical and Mechanical Contractors Limited respectively. These two associations are the main organizations representing the consultants and contractors in the Hong Kong construction industry.

A questionnaire was designed for collecting a large amount of data from the consultants and contractors. Listed in the first section of the questionnaire are the 56 delay factors (in 10 groups) identified from the literature review. The respondents were asked to rate the frequency and severity of the factors in causing construction delay. The ratings, for frequency of occurrence, are: ' 1 'never; ' 2 '- rare; '3'- occasional; ' 4 '- very frequent; and ' 5 '- always. The counterparts for severity are: ' 1 '- low;
'2'- slight; ' 3 '- moderate; ' 4 '- high; and ' 5 '- extremely high. In the second section, the questions asked the respondents about their working experience, job position and academic qualification. Written in English, the questionnaire was pilot-tested by a group of consultants and contractors. Following the suggestion of the pilot group, a Chinese version of the questionnaire was added to cater for some respondents who might not be conversant with some specific terminologies in the English version.

In the full-scale survey, a master email embedded with a hyperlink to the questionnaire was broadcast to the target respondents. The email recipients, in addition to completing the survey themselves, were requested to invite their colleagues to participate in the survey.

The first step taken in processing the data collected was to find out the frequency index based on the perceived frequency of occurrence of each delay factor (Eqn (1)). The severity index of each delay factor was calculated in a similar way (Eqn (2)). Using Eqn (3), the importance index of each delay factor was obtained (Akogbe, Feng 2013; Le-Hoai et al. 2008, Shebob et al. 2012). For the 10 factor groups (Table 1), their frequency, importance, and severity indices were calculated by averaging the corresponding indices of individual delay factors within the same group (Eqn (4)).

$$
\begin{gathered}
I_{F}=\frac{\sum_{i=1}^{R} r_{i} \times n_{F, i}}{R \times T_{F}} ; \\
I_{S}=\frac{\sum_{i=1}^{R} r_{i} \times n_{S, i}}{R \times T_{S}} ; \\
I_{M}=I_{F} \times I_{S} ; \\
I_{X, G}=\frac{\sum_{j=1}^{J} I_{X, j}}{J},
\end{gathered}
$$

where $n_{F, i}$ - number of responses for the $i^{\text {th }}$ rating for occurrence frequency of each factor; $n_{S, i}$ - number of responses for the $i^{\text {th }}$ rating for severity of each factor; $r_{i}$ rating of response; $I_{F}$ - frequency index; $I_{M}$ - importance index; $I_{S}$ - severity index; $I_{X, G}$ - factor group index $[X=$ $F]$ (frequency), $M$ (importance), or $S$ (severity)]; $J$ - number of factors in a factor group; $R$ - maximum rating of response; $T_{F}$ - total number of responses for occurrence frequency; $T_{S}$ - total number of responses for severity.

For testing the agreements between different groups of rankings of the delay factors and factor groups, the Spearman's rank correlation coefficient was calculated. Afterwards, factor analysis was conducted to identify the key delay factors and determine the structure of the correlation between related delay factors (Chan, Park 2005; Dogbegah et al. 2011; Fang et al. 2004). 
Table 1. Grouping and sources of delay factors

\begin{tabular}{cll}
\hline Group & \multicolumn{1}{c}{ Factors } & \multicolumn{1}{c}{ Sources } \\
\hline 1. Client & 1.1. Finance problem of client; 1.2. Late decision making of & Aibinu, Odeyinka (2006); Al-Khalil, \\
& $\begin{array}{l}\text { client; 1.3. Change of client's orders; 1.4. Conflicts of joint- } \\
\text { ownership of project; 1.5. Unrealistic design criteria }\end{array}$ & Al-Ghafly (1999); Al-Momani (2000); Assaf \\
& & et al. (1995); Assaf, Al-Hejji (2006); Chan, \\
& & Kumaraswamy (1997); Doloi et al. (2012); \\
& & El-Razek et al. (2008); Fong et al. (2006); \\
& & Kaming et al. (1997); Muhwezi et al. (2014); \\
& & Odeh, Battaineh (2002); Sambasivan, Soon \\
\hline
\end{tabular}

$\begin{array}{ll}\text { 2. Design } & \begin{array}{l}\text { 2.1. Wrong/inappropriate design; 2.2. Inadequate experience } \\ \text { of consultants; } 2.3 \text {. Long waiting for approval of drawings; }\end{array} \\ & \begin{array}{l}\text { 2.4. Long waiting for approval of equipment; } 2.5 \text {. Excessive } \\ \text { site supervision; } 2.6 \text {. Insufficient site staff from design team }\end{array}\end{array}$

3. Main 3.1. Suspension of work by main contractor; 3.2. Delay in

contractor handover of transformer rooms or other plant rooms; 3.3. Delay of finance payment to sub-contractors; 3.4. Delay of infrastructure/superstructure; 3.5. Delay of interior finish; 3.6. Inadequate planning and scheduling

\begin{tabular}{ll}
\hline 4. Electrical & 4.1. Poor experience and qualification; 4.2. Cash flow \\
contractor & problem of electrical contractor; 4.3. Insufficient electrical \\
& contractor; 4.4. Poor site management and supervision skills; \\
& 4.5. Lack of on-site coordination; 4.6. High degree of sub- \\
& contracting
\end{tabular}

5. Labour 5.1. Insufficient labour; 5.2. Low productivity in labour; 5.3. Poor workmanship and skills of labour; 5.4. Rework due to errors

6. Equipment 6.1. Insufficient materials; 6.2. Delay of materials/ fabrication; 6.3. Poor material quality; 6.4 Materials stolen; 6.5. Insufficient tools

7. System performance

7.1. Power failure; 7.2. Non-compliance of installation with regulations; 7.3. Incorrect cable wiring; 7.4. Excessive earth fault loop impedance; 7.5. Extraneous conductive parts not earthed; 7.6. Undersized or missing of separate circuit protective conductors for earthing continuity; 7.7. Missing of earth leakage circuit breaker or residual-current devices in circuits; 7.8. Segregation of different types of circuits in the same conduit; 7.9. Failure of generator operation to meet statutory requirement; 7.10. Failure of switchboard in Factory Acceptance Test; 7.11. Failure of switchboard in Site Acceptance Test; 7.12. Malfunction of equipment;

7.13. Unfitting of schematic wiring diagram with actual wiring arrangement

\begin{tabular}{ll}
\hline 8. Statutory & 8.1. Submission to Environmental Protection Department \\
submission & (EPD) for approval of generator chimney installation; \\
and & 8.2. Defects identified by EPD; 8.3. Submission for Power \\
inspections & $\begin{array}{l}\text { Company inspection; 8.4. Defects identified in Power } \\
\text { Company inspection; 8.5. Submission to Fire Services }\end{array}$ \\
& $\begin{array}{l}\text { Department (FSD) for obtaining Dangerous Goods License; } \\
\text { 8.6. Defects identified in FSD inspection; 8.7. Submission of } \\
\text { completion certificate for electrical installation }\end{array}$ \\
\hline 9. External & $\begin{array}{l}\text { 9.1. Claims for extension of time due to inclement weather; } \\
\text { 9.2. Labour dispute/strike }\end{array}$
\end{tabular}

\begin{tabular}{ll}
\hline 10. & 10.1. Lack of communication between parties; \\
Contractual & 10.2. Mistrust/disputes among parties \\
relationships &
\end{tabular}

Fong et al. (2006); Law (2002)

Chan, Kumaraswamy (1997); Doloi et al.

(2012); Fong et al. (2006); Hwang et al.

(2013); Long et al. (2004); Sambasivan, Soon (2007)

Assaf et al. (1995); Hwang et al. (2013); Odeh, Battaineh (2002); Kaming et al. (1997); Long et al. (2004); Sambasivan, Soon (2007)

Al-Momani (2000); Doloi et al. (2012);

Hwang et al. (2013); Kaming et al. (1997);

Long et al. (2004); Ogunlana et al. (1996); Sambasivan, Soon (2007)

Fong et al. (2006)

Al-Momani (2000); Chan, Kumaraswamy (1997); Long et al. (2004); Ogunlana et al. (1996); Semple et al. (1994); Sweis et al. (2008)

Doloi et al. (2012); El-Razek et al. (2008); Hwang et al. (2013); Sambasivan, Soon (2007); Semple et al. (1994) 


\section{Results and discussion}

The data collected were analyzed with the aid of the Statistical Package of the Social Sciences (SPSS). In total, 132 respondents returned the questionnaire they completed. 68 of them worked as contractors and the remaining 64 were consultants. The majority (over 90\%) of the contractor group were experienced practitioners with over five years of working experience. While highly experienced practitioners also composed much of the consultant group, a larger proportion (20.3\%), when compared with the contractor group, were those who had worked for less than five years. The respondents were highly educated; almost all had received education at the university level.

\subsection{Ranking of delay factors and factor groups}

The frequency index, severity index and the resultant importance index of each delay factor were calculated using Eqns (1) to (3). Among the top 10 delay factors (IM > $50 \%$ ), the most important ones were "insufficient labour", followed by "late decision making of client" and "insufficient electrical contractor" (Fig. 2). In the next tier of factors $(51 \% \leq \mathrm{IM} \leq 53 \%)$ were "cash flow problem of electrical contractor", "inadequate experience of consultants" and "change of client's orders". The lowest group of factors, with an importance index just above $50 \%$, consisted of "rework due to errors", lack of communication between parties", "poor workmanship and skills of labour" and "lack of on-site coordination". A summary of the calculated results, including the ranks of the factors determined according to the importance indices pertain- ing to both the consultant and contractor groups, is shown in Table 2.

Overall, the factor "insufficient labour" was of the highest importance. With insufficient labour supply, the usual implications are poor productivity and high wages, imposing financial burden on contractor companies. While "insufficient labour" was also rated by the consultant group as the most important, the contractor group regarded it as an important factor second to "late decision making of client". In practice, slowness of decision making would result in construction time overrun (Hwang et al. 2013). "Insufficient electrical contractor", which ranked second in the consultant group, was rated by the contractor group as the sixth most important factor. Inspections on the ranks of the remaining factors found that they generally differed between the two respondent groups, with the smallest difference occurred with "poor workmanship and skills of labour" and the biggest with "lack of on-site coordination". This latter finding is intriguing in that the contractors, who are familiar with onsite activities, regarded the lack of coordination of such activities as the third most important delay factor. The consultants, probably because they are less directly involved in on-site matters, considered the same factor the lowest among the top 10 delay factors.

For testing the agreement between the importance ranks of the full list of 56 delay factors perceived by the consultant group and the contractor group, the Spearman's rank correlation method was applied. The Spearman's rank coefficients (2-tailed significance) were found as: $0.805(0.000)$ for frequency index; $0.739(0.000)$ for

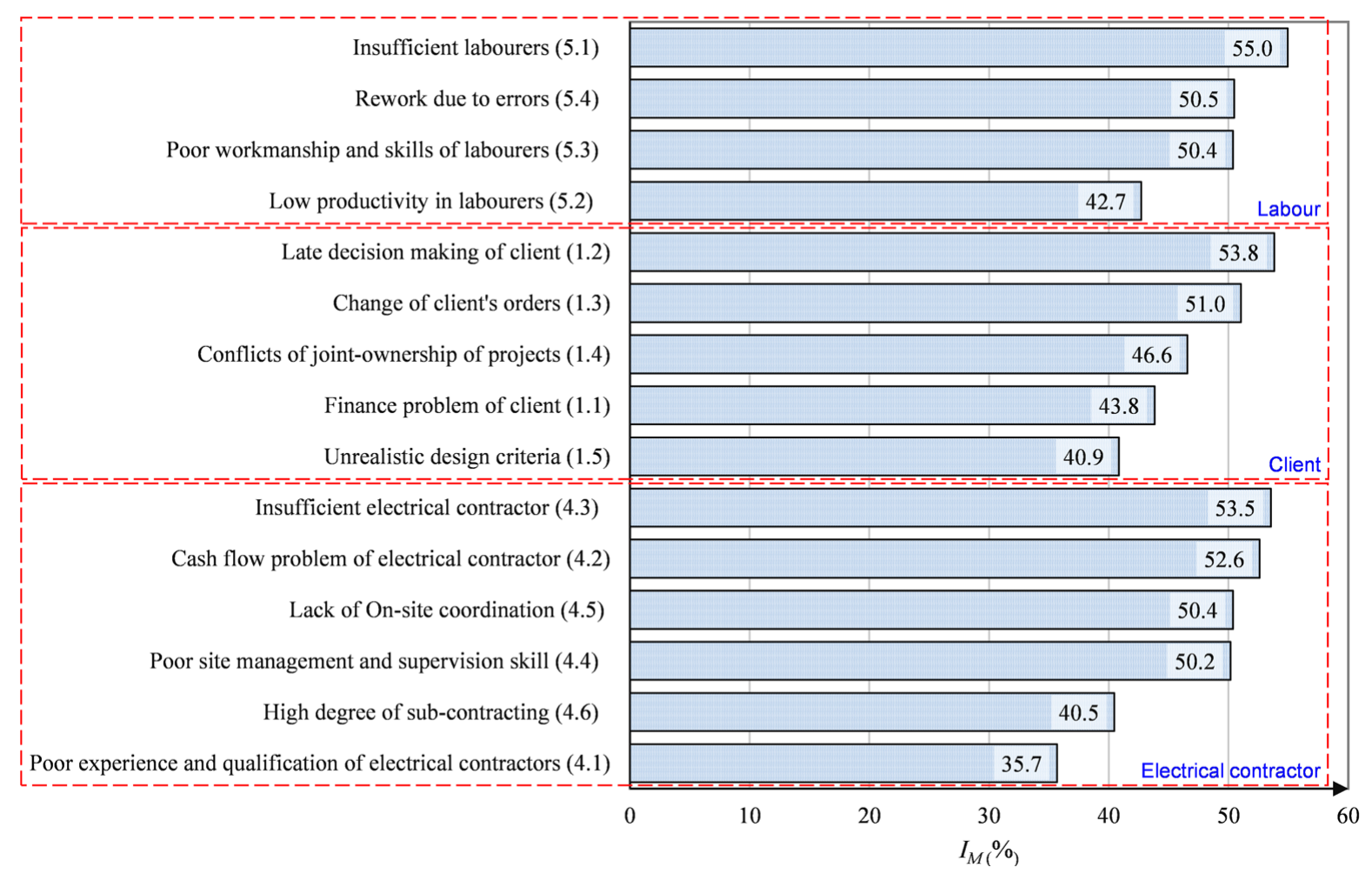

Fig. 2. Importance indices of factors in the top 3 factor groups 
Table 2. Indices and ranks of the top 10 delay factors

\begin{tabular}{|c|c|c|c|c|c|c|c|c|c|}
\hline \multirow[b]{2}{*}{ Factor } & \multirow{2}{*}{$\begin{array}{c}\text { Overall } \\
I_{M} \\
(\%)\end{array}$} & \multicolumn{4}{|c|}{ Consultant } & \multicolumn{4}{|c|}{ Contractor } \\
\hline & & $\begin{array}{c}I_{F} \\
(\%)\end{array}$ & $\begin{array}{c}I_{S} \\
(\%)\end{array}$ & $\begin{array}{c}I_{M} \\
(\%)\end{array}$ & Rank & $\begin{array}{c}I_{F} \\
(\%)\end{array}$ & $\begin{array}{c}I_{S} \\
(\%)\end{array}$ & $\begin{array}{c}I_{M} \\
(\%)\end{array}$ & Rank \\
\hline Insufficient labour & 55.0 & 74.1 & 76.6 & 56.7 & 1 & 69.7 & 76.5 & 53.3 & 2 \\
\hline Late decision making of client & 53.8 & 78.8 & 68.1 & 53.6 & 4 & 81.2 & 66.5 & 54.0 & 1 \\
\hline Insufficient electrical contractor & 53.5 & 74.7 & 74.7 & 55.8 & 2 & 69.4 & 74.1 & 51.4 & 6 \\
\hline Cash flow problem of electrical contractor & 52.6 & 76.9 & 70.6 & 54.3 & 3 & 79.1 & 64.4 & 51.0 & 7 \\
\hline Inadequate experience of consultants & 51.4 & 70.6 & 71.3 & 50.3 & $8=$ & 72.1 & 72.6 & 52.3 & 4 \\
\hline Change of client's orders & 51.0 & 70.9 & 70.9 & 50.3 & $8=$ & 71.8 & 72.1 & 51.7 & 5 \\
\hline Rework due to errors & 50.5 & 70.9 & 74.1 & 52.5 & 5 & 68.8 & 70.6 & 48.6 & 10 \\
\hline Lack of communication between parties & 50.5 & 72.8 & 70.3 & 51.2 & 6 & 71.2 & 70.0 & 49.8 & 9 \\
\hline Poor workmanship and skills of labour & 50.4 & 72.8 & 69.1 & 50.3 & $8=$ & 72.1 & 70.0 & 50.4 & 8 \\
\hline Lack of On-site coordination & 50.4 & 69.1 & 69.7 & 48.1 & 10 & 74.4 & 70.6 & 52.5 & 3 \\
\hline
\end{tabular}

severity index; and 0.828 (0.000) for importance index. These results show that there existed highly positive agreements between the two groups of factor rankings. The importance index of each of the 10 factor groups was obtained using Eqn (4). A summary of the results is shown in Table 3. Based on all the responses, the top-rated factor group is "labour", followed by "client" and "electrical contractor". On the other hand, the least important ones include: "system performance", "statutory submission/ inspections" and "external factors". The importance of "external factors", from the views of both the consultants and contractors, was the lowest. Closer examinations were made on the above three most important factor groups. In the "labour" group (Fig. 2), there are four factors, among them "insufficient labour" ranked first, and it was also considered the most important delay factor (see Fig. 2). Except "low productivity in labour", the second- and third-rated factors in the same group, i.e. "rework due to errors" and "poor workmanship and skills of labour" were also among the top 10 important factors (Fig. 2). Plausible reasons for the high importance of this group of factors include improper manpower planning, insufficient training for the labour, and low motivation for high productivity.

The importance rank of the factor group "client" was rated as the first by the contractors and the third by the consultants (Table 3 ). In this group, there are five factors, with the top-rated one being "late decision making of client", followed by "change of client's orders" (Fig. 2). Whereas variation works are often inevitable for construction projects, frequent and late orders of such works can ruin the plans of contractors and create substantial financial implications (Sweis et al. 2008). The client should provide a clear scope of work in the planning and design phase, which will help in minimizing variation orders (Enshassi et al. 2010). On the other hand, full understanding of the roles and responsibilities between clients and consultants are essential for avoiding non-compliance with clients' requirements (Le-Hoai et al. 2008).

"Insufficient electrical contractor" in the construction market is the most important factor in the "electrical contractor" group (Fig. 2). Engagement of incompetent contractors would result in slow progress or substandard quality of electrical installations, which in turn would have adverse effect on the other trades of construction works (Doloi et al. 2012; El-Razek et al. 2008). Such problems, if not detected and rectified promptly, would cause project delays (Odeh, Battaineh 2002; Doloi et al. 2012). The second most important factor in the "electrical contractor" group is "cash flow problem of electrical contractor". Usually the cost of electrical installation in a construction project is not small. Any surge in worker wages or delayed progress payments from a project client would create cash flow problems to the concerned contractor. In such a case, the client may enter into legal

Table 3. Importance indices and ranks of factor groups

\begin{tabular}{lcccccc}
\hline \multirow{2}{*}{ Factor group } & \multicolumn{2}{c}{ Overall } & \multicolumn{2}{c}{ Consultant } & \multicolumn{2}{c}{ Contractor } \\
\cline { 2 - 7 } & $I_{M, G}(\%)$ & Rank & $I_{M, G}(\%)$ & Rank & $I_{M, G}(\%)$ & Rank \\
\hline Client & 47.25 & 2 & 45.80 & 3 & 48.70 & 1 \\
Design team & 43.00 & 4 & 42.00 & 5 & 43.90 & 4 \\
Main contractor & 40.79 & 5 & 42.20 & 4 & 39.50 & 7 \\
Electrical contractor & 47.01 & 3 & 46.00 & 2 & 45.20 & 3 \\
Labour & 49.57 & 1 & 50.80 & 1 & 48.60 & 2 \\
Equipment & 38.40 & 7 & 39.50 & 7 & 40.50 & 5 \\
System performance & 35.09 & 8 & 32.90 & 9 & 37.20 & 8 \\
Statutory submission/inspections & 33.70 & 9 & 33.00 & 8 & 34.40 & 9 \\
External factors & 31.84 & 10 & 32.60 & 10 & 31.10 & 10 \\
Contractual relationships & 39.97 & 6 & 40.30 & 6 & 39.60 & 6 \\
\hline
\end{tabular}


dispute with the contractor and needs to re-tender to search for an alternative contractor (El-Razek et al. 2008). Apart from high legal cost, the extra time incurred for re-tendering is a common cause of delay in projects.

Referring to the importance ranks of the 10 factor groups rated by the consultant group and the contractor group, the Spearman's rank correlation coefficients for frequency index, severity index, and importance index were computed, and the coefficients (2-tailed significance) are: 0.915 (0.000), $0.806(0.005)$ and 0.915 $(0.000)$, respectively. These results, when compared with the counterpart pertaining to importance rankings of the 56 delay factors, indicate that even higher positive agreements existed between the factor group rankings of the two respondent groups.

\subsection{Factor analysis}

Factor analysis is a powerful statistical technique that can provide insight among numerous correlated but seemingly unrelated variables into a few underlying factors (Chan, Park 2005; Dogbegah et al. 2011; Fang et al. 2004). In this study, factor analysis was used to identify variability among the delay factors and determine the structure of the correlation between the factors. Space limitation prohibited a comprehensive account of all the 56 delay factors. Instead, factor analysis was carried out on the three most important factor groups (i.e. "labour", "client" and "electrical contractor") and the factors with an importance index not less than $50 \%$ (i.e. factors with relatively higher influence). The remaining factors, because of their low index values and hence insignificant impacts on construction delay, were excluded from the factor analysis. In total, three principal components were evolved from the principal component analysis using varimax orthogonal rotation. However, one delay factor - "change of client's orders", was excluded because of its significant loading on more than one component. The three components, with reference to the representations of their constituent factors, were labelled as "incompetent project team members" (Component 1), "lack of skillful labour" (Component 2) and "poor on-site planning" (Component 3). Altogether they explain $75 \%$ of the total variance, and their eigenvalue, percentage of variance and factor loading are summarised in Table 4.

\section{Component 1: Incompetent project team members}

Included in this component are factors concerning incompetence of various types of project team members. The component explains $44.7 \%$ of the total variance. It includes several key factors with high factor loading, namely "insufficient labour" (0.943), "insufficient electrical contractor" (0.874), "late decision making of client" (0.718), "poor site management and supervision skill" $(0.703)$ and "cash flow problem of electrical contractor" (0.649).

In fact, previous studies have shown that shortage of manpower is an important variable that contributes to delay in construction projects (Al-Kharashi, Skitmore 2009; Assaf et al. 1995; El-Razek et al. 2008; Hwang et al. 2013; Kazaz et al. 2012; Odeh, Battaineh 2002; Sweis et al. 2008). In Hong Kong, manpower shortage is also a common problem with construction projects. According to the manpower forecast for construction workers (Construction Industry Council 2014), only 70,000 out of the 320,000 registered construction workers are active workers and there would be a shortage of at least 10,000 workers in the following years. There is also an ageing problem in the construction industry; $44 \%$ of registered construction workers were aged over 50 (Construction Industry Council 2014). Given that insufficient manpower supply and aging workforce will lead to poor productivity and slow progress of work, signing longterm contracts with contractors' employees, should help ameliorate the problem in individual projects. Employers should also provide a safe working environment so as to attract young workers to join the construction industry (Ng, Chan 2015). For the whole construction industry, it is necessary to find ways for providing a sufficient and energetic workforce in the long run.

For project clients, their speed of decision making significantly affects the progress of project activities. A common reason for this problem is that the in-house teams for client organizations are in lack of sufficient expertise to handle some technical or contractual matters. This often happens in some specialist trades of work, e.g. when no standard forms of contracts are applicable (Lai et al. 2006). Even for large clients, they may not be able to make prompt decisions on new, complex issues. Similar problems may also arise when contractors

Table 4. Result of factor analysis

\begin{tabular}{|c|c|c|c|c|}
\hline Component & Eigenvalue & Variance & Factor & Loading \\
\hline 1. Incompetent project team members & 3.574 & $44.7 \%$ & $\begin{array}{l}\text { (1.2) Late decision making of client } \\
\text { (4.2) Cash flow problem of electrical contractor } \\
\text { (4.3) Insufficient electrical contractor } \\
\text { (4.4) Poor site management and supervision skill } \\
\text { (5.1) Insufficient labour }\end{array}$ & $\begin{array}{l}0.718 \\
0.649 \\
0.874 \\
0.703 \\
0.943\end{array}$ \\
\hline 2. Lack of skillful labour & 1.352 & $16.9 \%$ & (5.3) Poor workmanship and skills of labour & 0.946 \\
\hline 3. Poor on-site planning & 1.078 & $13.5 \%$ & $\begin{array}{l}\text { (4.5) Lack of on-site coordination } \\
\text { (5.4) Rework due to errors }\end{array}$ & $\begin{array}{l}0.919 \\
0.631\end{array}$ \\
\hline
\end{tabular}

Note: Bracketed numbers refer to the item numbers in Table 1. 
or consultants fail to make their clients realize the criticality of timely decision or when the clients' decisions are not properly conveyed to the relevant parties (Doloi et al. 2012). In any case, clients should make apt decisions and avoid unnecessary design changes that would result in abortive works.

"Poor site management and supervision skills" is another important factor that contributes to construction delay. Site management is related to material distribution, commitment of site employees, project monitoring and communication between project parties (Enshassi et al. 2009). Appropriate site management, which fosters productive construction activities, contributes to better management of project schedule (Hwang et al. 2013). But poor site management is a critical factor for construction delay (Chan, Kumaraswamy 1997; Kadir et al. 2005; Sambasivan, Soon 2007). For electrical contractors, improper site management is often a result of reluctance to invest in project planning or lack of project manager's involvement in on-site activities (Odeh, Battaineh 2002).

Lack of competent site management staff may also lead to various problems such as unwanted conflicts, improper coordination and negative work attitudes, thereby causing project delays. Coordination of site boundary utilities, in particular, is a challenging site management work. For underground utilities (e.g. electrical cables, gas pipes, sewers) to be properly coordinated, site surveys and trial pits are required before commencement of construction work (Chan, Kumaraswamy 1997). Regular site meetings among relevant parties, including the electrical contractor and contractors of other trades of building services (Yik et al. 2006) to resolve any on-site conflicts would prevent work suspension.

Financial issues are definitely critical to construction delay. A number of studies have found that contractors' financial difficulties, which are related to overdue progress payments, are among the major attributes that contribute to construction delay (Al-Kharashi, Skitmore 2009; Aibinu, Odeyinka 2006; El-Razek et al. 2008; Odeh, Battaineh 2002). As huge amounts of money are needed to finance construction works, contractors are required to pay considerable upfront expenses, which are recovered later from clients' payments, typically on a monthly basis. Any late submission of payment applications or deferred payments from the clients would affect the contractors' financial situation. It is not uncommon that for contractors who failed to properly manage their cash flow, their workers went on strike, causing project delay.

\section{Component 2: Lack of skillful labour}

Labelled as "lack of skillful labour" and explaining $16.9 \%$ of the total variance, the second component contains a single factor - poor workmanship and skills in labour. It is widely known that a low quality workforce is detrimental to the progress of a construction project. In Hong Kong, the shortage of skillful workers makes it difficult to cope with tight construction programmes, not to mention completing projects in time. In 2015, the government reported that there were shortfalls in technicians, craftsmen and semi-skilled workers in various trades of electrical and mechanical works in the previous five years (Secretary of Labour and Welfare 2015). Nowadays, skillful workers remain as one of the scarcest resources amidst the large volumes of construction projects in Hong Kong. Whereas the shortfall of skillful workers may be attributed to the low pay, long working hours and poor career path image of the construction industry, contractors often resort to cheap, unskilled labour as a result of insufficient skilled workers. The common consequences are poor work quality, low productivity and hence longer construction period. To ameliorate the lack of skillful workers, clients should also avoid acceptance of unreasonably low tender bids. On the contrary, providing incentives for contractors to use high quality workers should be encouraged, as such measures can promote good workmanship and less rework, thereby minimizing project delay.

\section{Component 3: Poor on-site planning}

The third component is "poor on-site planning". It embraces two key attributes, namely "lack of site coordination" and "rework due to errors", which are some problems directly related to the daily operations of contractors. For electrical installations in Hong Kong, registered electrical contractors (RECs) have to coordinate with various trades of contractors to plan for their on-site activities, as the RECs are required by law to consolidate work completion certificate for their own electrical installations and certificates of the same sorts for other trades of building services (e.g. air-conditioning, lifts and escalators, etc.) involving electrical work. Such certificates, in accordance with the Code of Practice for the Electricity (Wiring) Regulations, must be submitted to the Electrical and Mechanical Services Department (EMSD) before the electrical installations could be energized (EMSD 2015). Since temporary power supply is often unable to cope with large electrical demand in testing and commissioning building services installations, timely completion of electrical work is essential. Slip in handing over the transformer rooms to the power companies (CLP 2001; HEC 2005 ) would delay connection of power supply to the electrical installations. Electrical switchboards, switchgears, distribution boards, cables, energy meters and so on, if not properly planned for installation, could also cause delay in power supply connection.

Construction projects involve various parties, including clients, consultants and contractors. Any misunderstanding between these parties about the site situation would compel contractors to compromise quality of construction, leading to mistakes and reworks (Doloi et al. 2012; Hwang et al. 2013). In cases of disputes over such liabilities, a common consequence is delay in the subsequent construction activities. Therefore, it is imperative to have proper planning for on-site activities. 


\section{Conclusions}

As an essential part of every construction project, electrical installation is needed not only for permanent use after project completion but also temporary power supply in testing and commissioning various engineering services during the construction period. As a typical critical path activity in construction projects, electrical installation has to be completed on schedule in order not to cause project delay.

Whereas a significant volume of research had been devoted to investigate construction project delay, research on delays that arise from problems with electrical installations were unavailable. In bridging this knowledge gap, the study found that 56 delay factors, belonging to 10 groups, are applicable to the electrical trade. On this basis, a map of the factor groups was constructed to serve as a guiding framework for formulating future research on project delay.

Through the questionnaire survey, useful responses were received from electrical consultants and contractors. The top delay factors identified include insufficient labour, late decision making of client and insufficient electrical contractor. The two groups, consultant and contractor, expressed highly consistent views on the importance ranking of the delay factors. "Labour", "client" and "electrical contractor" were considered the most critical groups of delay factors. Nevertheless, the fact that clients were not included in the research sample is a limitation of the current study. Studies in the future should investigate the experiences and opinions of other project stakeholders (e.g. clients, equipment suppliers) on the delay factors of electrical construction.

"Incompetent project team members", "lack of skillful labour" and "poor on-site planning", as unveiled from the factor analysis, are influential to project delay. Existence of such components in construction projects, therefore, should be prevented. Problem issues in each component have been discussed and recommended measures have been given for tackling the issues. In addition to taking a fresh perspective to investigate the old, chronic problems of project delay, the study provided valuable information that is crucial to the understanding of the problems. While these deliverables are useful findings for construction practitioners and the study's approach can serve as reference for future research in engineering and construction management, further studies are needed to explore how the recommended measures could be implemented effectively and investigate their effectiveness in avoiding project delay.

\section{References}

Aibinu, A.; Odeyinka, H. 2006. Construction delays and their causative factors in Nigeria, Journal of Construction Engineering and Management 132(7): 667-677.

https://doi.org/10.1061/(ASCE)0733-9364(2006)132:7(667)
Akogbe, R.-K. T.; Feng, X. Z. 2013. Importance ranking evaluation of delay factors for development construction projects in Benin, KSCE Journal of Civil Engineering 17(6): 1213-1222. https://doi.org/10.1007/s12205-013-0446-2

Al-Khalil, M. I.; Al-Ghafly, M. 1999. Important causes of delay in public utility projects in Saudi Arabia, Construction Management and Economics 17(5): 647-655. https://doi.org/10.1080/014461999371259

Al-Kharashi, A.; Skitmore, M. 2009. Causes of delays in Saudi Arabian public sector construction projects, Construction Management and Economics 27: 3-23. https://doi.org/10.1080/01446190802541457

Al-Momani, A. 2000. Construction delay: a quantitative analysis, International Journal of Project Management 18(1): 51-59. https://doi.org/10.1016/S0263-7863(98)00060-X

Assaf, S.; Al-Hejji, S. 2006. Causes of delay in large construction projects, International Journal of Project Management 24: 349-357. https://doi.org/10.1016/j.ijproman.2005.11.010

Assaf, S.; Al-Khalil, M.; Al-Hazmi, M. 1995. Causes of delays in large building projects, Journal of Management in Engineering 11(2): 45-50. https://doi.org/10.1061/(ASCE)0742-597X(1995)11:2(45)

Chan, D.; Kumaraswamy, M. 1993. A survey of time-cost relationships in Hong Kong construction projects, Building Technology and Management 20(1): 54-72.

Chan, D.; Kumaraswamy, M. 1997. A comparative study of causes of time overruns in Hong Kong construction projects, International Journal of Project Management 15(1): 55-63. https://doi.org/10.1016/S0263-7863(96)00039-7

Chan, D.; Kumaraswamy, M. 2002. Compressing construction durations: lessons learned from Hong Kong building projects, International Journal of Project Management 20: 23-35. https://doi.org/10.1016/S0263-7863(00)00032-6

Chan, S.; Park, M. 2005. Project cost estimation using principal component regression, Construction Management and Economics 23: 295-304. https://doi.org/10.1080/01446190500039812

Chi, C.F.; Yang, C.C.; Chen, Z. L. 2009. In-depth accident analysis of electrical fatalities in the construction industry, International Journal of Industrial Ergonomics 39(4): 635-644. https://doi.org/10.1016/j.ergon.2007.12.003

Construction Industry Council (CIC). 2014. Report of CIC manpower forecasting model 2014 (Workers). Construction Industry Council, Hong Kong.

China Light and Power (CLP). 2001. Supply rules. CLP Power Hong Kong Limited, Hong Kong.

Dogbegah, R.; Owusu-Manu, D.; Omoteso, K. 2011. A principal component analysis of project management competencies for the Ghanaian Construction Industry, Australasian Journal of Construction Economics and Building 11(1): 26-40. https://doi.org/10.5130/ajceb.v11i1.1680

Doloi, H.; Sawhney, A.; Iyer, K.; Rentala, S. 2012. Analysing factors affecting delays in Indian construction projects, International Journal of Project Management 30: 479-489. https://doi.org/10.1016/j.ijproman.2011.10.004

El-Razek, M.; Bassioni, H.; Mobarak, A. 2008. Causes of delay in building construction projects in Egypt, Journal of Construction Engineering and Management 134(11): 831-841. https://doi.org/10.1061/(ASCE)07339364(2008)134:11(831)

Electrical and Mechanical Services Department (EMSD). 2015. Code of practice for the electricity (wiring) regulations. The Government of the Hong Kong Special Administrative Region, Hong Kong.

Enshassi, A.; Al-Najjar, J.; Kumaraswamy, M. 2009. Delay and cost overruns in the construction projects in the Gaza 
Strip, Journal of Financial Management of Property and Construction 14(2): 126-151.

https://doi.org/10.1108/13664380910977592

Enshassi, A.; Arain, F.; Al-Raee, S. 2010. Causes of variation orders in construction projects in the Gaza Strip, Journal of Civil Engineering and Management 16(4): 540-551. https://doi.org/10.3846/jcem.2010.60

Fang, D.; Xie, F.; Huang, X.; Li, H. 2004. Factor analysis-based studies on construction workplace safety management in China, International Journal of Project Management 9(3): 458-467. https://doi.org/10.1016/s0263-7863(02)00115-1

Fong, N. K.; Wong, L.; Wong, L. 2006. Fire services installation related contributors of construction delays, Building and Environment 41(1): 211-222. https://doi.org/10.1016/j.buildenv.2005.01.004

Hanna, A. S.; Menches, C. L.; Sullivan, K. T.; Sargent, J. R. 2005. Factors affecting absenteeism in electrical construction, Journal of Construction Engineering and Management 131(11): 1212-1218. https://doi.org/10.1061/ (ASCE)0733-9364(2005)131:11(1212)

Hong Kong Electric Company Limited (HEC). 2005. Guide to connection of supply. HEC, Hong Kong.

Hemanta, D.; Anil, S.; Iyer, K.; Sameer, R. 2012. Analysing factors affecting delays in Indian construction projects, International Journal of Project Management 30(4): 479-489. https://doi.org/10.1016/j.ijproman.2011.10.004

Horman, M. J.; Orosz, M. P.; Riley, D. R. 2006. Sequence planning for electrical construction, Journal of Construction Engineering and Management 132(4): 363-372.

https://doi.org/10.1061/(ASCE)0733-9364(2006)132:4(363)

Hwang, B.; Zhao, X.; Ng, S. Y. 2013. Identifying the critical factors affecting schedule performance of public housing projects, Habitat International 38: 214-223.

https://doi.org/10.1016/j.habitatint.2012.06.008

Kadir, M.; Lee, W.; Jaafar, M.; Sapuan, S.; Ali, A. 2005. Factors affecting construction labour productivity for Malaysian residential projects, Structural Survey 23: 42-54. https://doi.org/10.1108/02630800510586907

Kaming, P.; Olomolaiye, P.; Holt, G.; Harris, F. 1997. Factor influencing construction time and cost overruns on high rise projects in Indonesia, Construction Management and Economics 15: 83-94. https://doi.org/10.1080/014461997373132

Kazaz, A.; Ulubeyli, S.; Tuncbilekli, N. A. 2012. Causes of delays in construction projects in Turkey, Journal of Civil Engineering and Management 18(3): 426-435. https://doi.org/10.3846/13923730.2012.698913

Lai, J. H. K.; Yik, F. W. H.; Jones, P. 2006. Critical contractual issues of outsourced operation and maintenance service for commercial buildings, International Journal of Service Industry Management 17(4): 320-343. https://doi.org/10.1108/09564230610680640

Lai, J. H. K .; Yik, F. W. H.; Chan, K. T.; Lee, W. L.; Chau, C. K. 2011. Regulatory controls on building services works in Hong Kong, Construction Law Journal 27(6): 459-479.

Law, S. 2002. Application for an occupation permit, in Proceedings of Building Engineers and the BO, 8 March 2002, Hong Kong, 59-79.

Le-Hoai, L.; Lee, Y.; Lee, J. 2008. Delay and cost overruns in Vietnam large construction projects: A comparison with other selected countries, KSCE Journal of Civil Engineering 12(6): 367-377.

https://doi.org/10.1007/s12205-008-0367-7

Long, D.; Stephen, O.; Quang, T.; Lam, K. 2004. Large construction projects in developing countries: a case study from Vietnam, International Journal of Project Management 22: 553-561.

https://doi.org/10.1016/j.ijproman.2004.03.004
Menches, C. L.; Hanna, A. S. 2006. Conceptual planning process for electrical construction, Journal of Construction Engineering and Management 132(12): 1306-1313.

https://doi.org/10.1061/(ASCE)0733-9364(2006)132:12(1306)

Menches, C. L.; Hanna, A. S.; Nordheim, E. V.; Russell, J. S. 2008. Impact of pre-construction planning and project characteristics on performance in the US electrical construction industry, Construction Management and Economics 26(8): 855-869. https://doi.org/10.1080/01446190802213511

Mezher, T.; Tawil, W. 1998. Causes of delays in the construction industry in Lebanon, Engineering Construction and Architectural Management 5(3): 251-260. https://doi.org/10.1108/eb021079

Muhwezi, L.; Acai, J.; Otim, G. 2014. An assessment of the factors causing delays on building construction projects in Uganda, International Journal of Construction Engineering and Management 3(1): 13-23.

Ng, J. Y. K.; Chan, A. H. S. 2015. The ageing construction workforce in Hong Kong: A review, in Proceedings of the International MultiConference of Engineers and Computer Scientists, 18-20 March 2015, Hong Kong, 23-26.

Odeh, A.; Battaineh, H. 2002. Causes of construction delay: traditional contracts, International Journal of Project Management 20: 67-73. https://doi.org/10.1016/S0263-7863(00)00037-5

Ogunlana, S.; Promkuntong, K.; Jearkjirm, V. 1996. Construction delays in a fast-growing economy: comparing Thailand with other economies, International Journal of Project Management 14(1): 37-45. https://doi.org/10.1016/0263-7863(95)00052-6

Rwelamila, P.; Hall, K. 1995. Total systems intervention: an integrated approach to time, cost and quality management, Construction Management and Economics 13(1): 235-241. https://doi.org/10.1080/01446199500000027

Sambasivan, M.; Soon, Y. 2007. Causes and effects of delays in Malaysian construction industry, International Journal of Project Management 25: 517-526. https://doi.org/10.1016/j.ijproman.2006.11.007

Secretary of Labour and Welfare 2015. Response to the LCQ11: Shortage of technical personnel in electrical and mechanical works under construction industry [online], [cited 30 March 2016]. Available from Internet: www.info.gov.hk/ gia/general/201503/25/P201503250565.html

Semple, C.; Hartman, F.; Jergeas, G. 1994. Construction claims and disputes: causes and cost/time overruns, Journal of Construction Engineering and Management 120(4): 785-795. https://doi.org/10.1061/(ASCE)07339364(1994)120:4(785)

Shebob, M.; Dawood, N.; Shah, R.; Xu, Q. 2012. Comparative study of delay factors in Libyan and the UK construction industry, Engineering Construction and Architectural Management 19(6): 688-712. https://doi.org/10.1108/09699981211277577

Smith, J. G.; Hinze, J. 2010. Construction management: subcontractor scopes of work. Boca Raton, FL.: CRC Press.

Sweis, G.; Sweis, R.; Ha, A.; Shboul, A. 2008. Delays in construction projects: The case of Jordan, International Journal of Project Management 26: 665-674. https://doi.org/10.1016/j.ijproman.2007.09.009

Wang, W. C.; Lim, C. L.; Wang, S.H.; Liu, J. J.; Lee, M. T. 2014. Allocation of importance-satisfaction analysis and influence-relations map to evaluate design delay factors, Journal of Civil Engineering and Management 20(4): 497-510. https://doi.org/10.3846/13923730.2013.801922

Yik, F. W. H.; Lai, J. H. K.; Chan, K. T.; Yiu, E. C. Y. 2006. Problems with specialist subcontracting in the construction industry, Building Services Engineering Research and Technology 27(3): 183-193. https://doi. org/10.1191/0143624406bse160oa 
Yik, F. W. H.; Lai, J. H. K. 2008. Multilayer subcontracting of specialist works in buildings in Hong Kong, International Journal of Project Management 26: 399-407. https://doi.org/10.1016/j.ijproman.2007.05.009

Betty W. Y. CHIU. Is a Lecturer in the Department of Construction at the Hong Kong Institute of Vocational Education. She received her PhD degree from Department of Real Estate and Construction, The University of Hong Kong in 2012. She formerly worked as an Instructor in the Department of Building Services Engineering, The Hong Kong Polytechnic University. Her research interests include construction project management and construction time management.

Joseph H. K. LAI. Is an Associate Professor in the Department of Building Services Engineering, The Hong Kong Polytechnic University (PolyU). With a first-class honours degree in building services engineering, a master degree in environmental management and a PhD in facilities management, Dr Lai is a registered professional engineer who had practised for over a decade before embarking on his academic career. Being the Facility Management Programme Leader of PolyU, Dr Lai focuses his research on facilities engineering and management, and he has published widely in international journals. Serving as Co-Editor of the journal "Facilities" and a Regional Editor of the journal "Smart and Sustainable Built Environment", Dr Lai is also on the committees of various professional institutions and public bodies. 